\title{
Molecular tools for differentiating Cyclaneusma minus morphotypes and assessing their distribution in Pinus radiata forests in New Zealand
}

\author{
Shannon Hunter ${ }^{1}$, Morag Glen ${ }^{2}$ and Rebecca McDougal ${ }^{1 *}$
}

\begin{abstract}
Background: Cyclaneusma needle cast (CNC) is a pine disease caused by the ascomycetous fungus Cyclaneusma minus (Butin) DiCosmo, Peredo and Minter. The pathogen occurs worldwide but is of particular significance in New Zealand where it infects Pinus radiata D. Don plantations. There are two morphological types of C. minus, termed C. minus 'simile' and C. minus 'verum', recently shown by multigene phylogenetic analysis to belong to distinct clades and therefore proposed to be two separate species. It is currently unknown whether one or both of these molecular operational taxonomic units (MOTUs) are responsible for CNC.
\end{abstract}

Methods: In this study, DNA analysis of the rDNA internal transcribed spacer (ITS) region was carried out on 120 isolates of C. minus collected in New Zealand since 1969 to distinguish C. minus simile from C. minus verum. Specific primers for C. minus simile and C. minus verum were developed for molecular differentiation from pure cultures and direct amplification from infected needles. Using these specific primers, the distribution of C. minus simile and verum was determined from isolates collected throughout New Zealand.

Results: The C. minus simile and C. minus verum primers developed were specific to these morphotypes only and were successfully used to identify simile and verum MOTUs from culture. Morphological typing of cultures was consistent with specific primer results in only $56 \%$ of isolates tested, demonstrating the high level of skill and experience required for accurate morphotyping from culture alone. C. minus simile was more common throughout New Zealand including regions where CNC is known to be more prevalent. From a collection of 120 isolates, 89\% of North Island isolates and 59\% of the South Island isolates were C. minus simile. The C. minus simile and verum specific primers were used to detect Cyclaneusma DNA in symptomatic $P$. radiata needles. C. minus simile was detected in 39\% of the needle samples and C. minus verum was only detected in 11\%. However, Cyclaneusma DNA was not detected by PCR in 50\% of the sampled needles.

Conclusions: The molecular methods developed for differentiation of $C$. minus simile and C. minus verum can be used to rapidly identify these morphotypes from cultures or from infected needles, which reduces the time otherwise required for morphological identification. Analysis using these tools for characterisation of C. minus sensu lato, isolated from P. radiata plantations in New Zealand since 1969, revealed that C. minus simile was more common than C. minus verum.

Keywords: Polymerase chain reaction (PCR), Molecular diagnosis, Cyclaneusma needle cast (CNC), Cyclaneusma niveum, Morphotypes, MOTU

\footnotetext{
* Correspondence: Rebecca.McDougal@scionresearch.com

${ }^{1}$ Scion, New Zealand Forest Research Institute Ltd., Private Bag 3020, Rotorua

3046, New Zealand

Full list of author information is available at the end of the article
} 


\section{Background}

Cyclaneusma needle cast $(\mathrm{CNC})$ is a foliar disease of many Pinus species worldwide (Bednářová et al. 2013; Choi and Simpson 1991; Crous et al. 1990; Gadgil 1984; Giordano and Gonthier 2011; Kistler and Merrill 1977). The disease is caused by the ascomycetous fungus Cyclaneusma minus (Butin) DiCosmo, Peredo and Minter (DiCosmo et al. 1983). The impact of CNC is especially high in exotic Pinus radiata D.Don plantations in New Zealand (Bulman 1988) and Australia (Choi and Simpson 1991). Cyclaneusma minus is also present in needles of healthy and susceptible trees as a fungal endophyte (Helander et al. 1994; Kowalski 1993; Sieber et al. 1999). Presently, there are two described Cyclaneusma species, C. minus and $C$. niveum (Pers.) DiCosmo, Peredo and Minter (DiCosmo et al. 1983). Both of these are found in New Zealand but only C. minus is associated with $\mathrm{CNC}$ on $P$. radiata (Gadgil 1984). Two morphological types of $C$. minus have been defined, termed C. minus 'simile' and C. minus 'verum, based on colony morphology and measurements of apothecial length (Dick et al. 2001). Recent research using molecular methods has shown that the two morphotypes are likely to be separate species based on phylogenetic analysis with multiple gene regions. These two morphotypes also differ by an indel of $192 \mathrm{bp}$ in the $18 \mathrm{~S}$ rDNA (Prihatini et al. 2014). However, because species descriptions have not yet been proposed we refer to these as molecular operational taxonomic units (MOTUs) when the isolates have been distinguished based on molecular assessments.

Pinus radiata makes up $90 \%$ of the planted forests in New Zealand (New Zealand Forest Owners Association 2012). Cyclaneusma needle cast in susceptible $P$. radiata results in premature casting of needles and, over time, a reduction in growth (van der Pas et al. 1984). The estimated financial loss from reduced growth amounts to \$38 million NZD per annum (Bulman 2009), which has a substantial effect on the New Zealand economy. Studies of potential control methods have shown that chemical control is not economically viable. However, thinning of trees at an age where disease symptoms are obvious (7 to 10 years) but before they cause substantial damage could reduce disease impact at the stand level by removing susceptible trees in Bulman and Gadgil (2001) and Hood and Vanner (1984). The use of resistant cultivars of $P$. radiata may be the most suitable means of control (Dungey et al. 2006) and elimination of highly susceptible genotypes from the $P$. radiata breeding population has already reduced the impact of this disease in New Zealand (Bulman 2009).

The distribution of CNC in New Zealand was surveyed in 15 forests (totalling more than 70,000 ha of $P$. radiata) from 1983 to 1985 (Bulman 1988). It was discovered that Northland, Gisborne, Bay of Plenty and
Taupo regions of the North Island had the highest severity of the disease, and the lowest disease incidence was in Canterbury and Nelson regions of the South Island (Bulman and Gadgil 2001). Stands aged 11 to 20 years old have the highest measured disease severity, while stands under 5 years old and over 25 years old have the lowest measured disease severity (Bulman 1988; Bulman and Gadgil 2001). Geographic distribution of the morphotypes was also analysed using morphological and cultural characters in isolates obtained from $P$. radiata needles showing symptoms of $\mathrm{CNC}$ that were collected from 1977-1983 and 1996-1998. The verum morphotype was found to be the most common overall but simile morphotype was more common in the North Island (Dick et al. 2001).

As the most promising method for control currently appears to be cultivation of tolerant or resistant $P$. radiata genotypes, it is necessary to understand the genetic diversity within the genus Cyclaneusma in order to successfully identify the most resistant host genotypes for cultivation on disease-prone sites. Symptoms and diagnostic features of $\mathrm{CNC}$ include yellow-green mottling of the pine needles, which eventually turn brown and can be easily shaken from the tree. Cyclaneusma minus morphotypes can be isolated and cultured from these needles and then identified based on morphological assessment of these cultures. However, variability has been observed previously under different culture conditions (Dick et al. 2001) and environmental factors (Podger and Wardlaw 1990). Cyclaneusma minus is a slow growing fungus; therefore, analysis of morphological characters takes a considerable amount of time (Dick et al. 2001). Although genetic analyses of Cyclaneusma species have been performed previously (Prihatini et al. 2014, 2015), molecular methods for rapid diagnosis and characterisation are not yet available. The aims of this study were to (i) develop specific primers for C. minus simile and C. minus verum that could be used in conventional or real-time polymerase chain reaction (PCR) and (ii) use these specific primers to determine the prevalence and distribution of $C$. minus simile and $C$. minus verum from isolates of $C$. minus obtained from symptomatic $P$. radiata needles collected throughout New Zealand between 1998 and 2008.

\section{Methods \\ Isolates}

The New Zealand C. minus isolates used in this study (Additional file 1: Table S1, $n=120$ ) were obtained from symptomatic $P$. radiata needles collected from locations in New Zealand from 1969 to 2008 and were obtained from the Forest Research Culture Collection (NZFS) located at Scion, New Zealand. Cyclaneusma minus type strain (CBS 496.73) and C. niveum neotype strain (CBS 495.73) were obtained from the CBS-KNAW culture 
collection in Utrecht, The Netherlands. Cyclaneusma minus strains were grown on $2 \%$ malt agar at $20{ }^{\circ} \mathrm{C}$ for approximately 14-21 days. Morphological analyses of the gross colony morphology was performed and recorded for each cultured isolate tested according to the descriptions in Dick et al. (2001).

\section{Primer design}

Selected internal transcribed spacer (ITS) DNA sequences were obtained from an alignment in the TreeBase database (Prihatini et al. 2014) and re-aligned with sequences of the ITS regions, from $C$. minus simile and verum, the $C$. minus type strain (CBS 496.73) and the C. niveum neotype strain (CBS 495.73) using the multiple sequence alignment programme MAFTT (Katoh et al. 2002) in the Geneious software (version 7.1.8, http://www.geneious.com, (Kearse et al. 2012)) (Fig. 1). Primer sequences were designed for DNA regions where nucleotide variations were observed between the two morphotypes (Fig. 1, Table 1). Primer sequences were checked for potential secondary structures using an online oligonucleotide properties calculator (http:// www.basic.northwestern.edu/biotools/oligocalc.html). Primer sequences were also checked for similarity with other DNA sequences by performing a BLAST search (Altschul et al. 1990) in GenBank (National Centre for Biotechnology Information, MD, USA).

\section{DNA extraction}

Cyclaneusma minus cultures were grown on $2 \%$ malt agar, as described above, but with cellophane overlaid on the medium. The mycelium was scraped off the cellophane into Lysing Matrix A tubes and DNA was extracted using the FastDNA kit and cell lysis solution CLS-Y (MP Biomedicals, OH, USA), according to the manufacturer's instructions. DNA integrity was checked by agarose gel electrophoresis on $0.8 \%$ agarose gels, run at $100 \mathrm{~V}$ for $35 \mathrm{~min}$. Gels were stained with RedSafe Nucleic Acid Staining Solution (iNtRON Biotechnology, Korea) and visualised by UV transillumination. DNA was quantified using a NanoDrop ${ }^{\mathrm{Tw}} 1000$ spectrophotometer (Thermo Scientific, Waltham, MA, USA) and stored at $4{ }^{\circ} \mathrm{C}$ (short term) or $-20{ }^{\circ} \mathrm{C}$ (long term).

\section{PCR and DNA sequencing}

The PCR primers used in this study are listed in Table 1. Conventional PCR reactions were performed using the KAPA2G Robust HotStart Readymix (2x) (KAPA Biosystems, MA, USA), according to the manufacturer's instructions. Each $25 \mu \mathrm{L}$ PCR reaction contained $6.75 \mu \mathrm{L}$ of PCR grade water, $12.5 \mu \mathrm{L}$ KAPA2G Robust HotStart ReadyMix $(2 \times), 1.25 \mu \mathrm{L}$ of each primer $(10 \mu \mathrm{M}), 1.25 \mu \mathrm{L}$ DMSO, and $2 \mu \mathrm{L}$ DNA (1-20 ng). Thermal cycling conditions consisted of an initial denaturation step of $95^{\circ} \mathrm{C}$ for $3 \mathrm{~min}$, then 35 cycles of $95^{\circ} \mathrm{C}(15 \mathrm{~s})$, annealing at primer-specific temperatures (Table 1) for $15 \mathrm{~s}$, and $72{ }^{\circ} \mathrm{C}(15 \mathrm{~s})$, and a final extension step of $72{ }^{\circ} \mathrm{C}$ (10 min). Gel electrophoresis was performed with $1 \%$ $(w / v)$ agarose in TBE and visualised by UV transillumination after staining with Redsafe Nucleic Acid Staining Solution (iNtRON Biotechnology, Seongnam, South

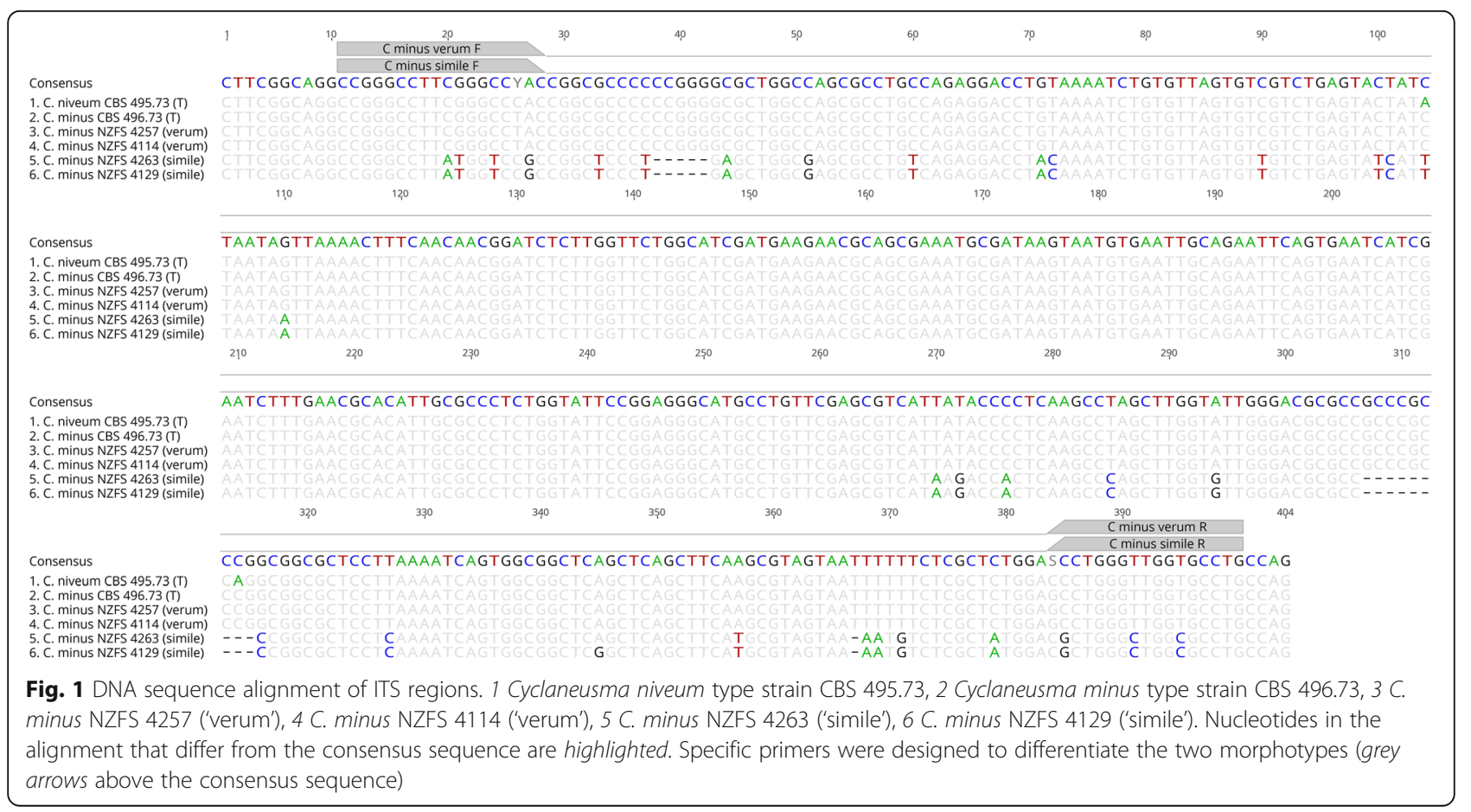


Table 1 Primers used in this study

\begin{tabular}{|c|c|c|c|c|}
\hline Gene region & Primer set & Sequence $\left(5^{\prime}-3^{\prime}\right)$ & Annealing temperature $\left({ }^{\circ} \mathrm{C}\right)$ & Reference \\
\hline \multirow[t]{2}{*}{ ITS } & ITS1-F & CCTGGTCATTTAGAGGAAGTAA & 55 & (Gardes and Bruns 1993 \\
\hline & ITS4 & TCCTCCGCTTATTGATATGC & & \\
\hline \multirow[t]{2}{*}{$\mathrm{Cm}^{\mathrm{a}}$ 'simile' specific ITS } & Cm 'simile' F & CCGGGCCTTATGGTCCGC & 63 & (This study) \\
\hline & Cm 'simile' R & CAGGCGCCAGCCCAGCG & & \\
\hline \multirow[t]{2}{*}{$\mathrm{Cm}^{\mathrm{a}}$ 'verum' specific ITS } & $\mathrm{Cm}$ 'verum' $\mathrm{F}$ & CCGGGCCTTCGGGCCTAC & 63 & (This study) \\
\hline & Cm 'verum' $\mathrm{R}$ & CAGGCACCAACCCAGGC & & \\
\hline
\end{tabular}

${ }^{a} \mathrm{Cm}$ Cyclaneusma minus. These primers were used for both conventional and real-time PCR

Korea). A 100-bp DNA ladder (Solis BioDyne, Tartu, Estonia) was used during electrophoresis for estimation of PCR product size.

Real-time PCR reactions were performed using PerfeCTa $^{\text {тм }}$ SYBR $^{\odot}$ Green FastMix ${ }^{\text {тм }}$ (Quanta Biosciences, Gaithersburg, MD, USA). PCR reactions were performed in $10 \mu \mathrm{L}$ volumes containing $5 \mu \mathrm{L} \operatorname{PerfeCTa}^{\text {тм }}$ SYBR green master mix $(2 \times), 0.3 \mu \mathrm{L}$ each primer $(10 \mu \mathrm{M}$; $300 \mathrm{nM}$ final concentration), $1 \mu \mathrm{L}$ volume of DNA template (1-20 ng), and 3.4 $\mu \mathrm{L}$ of PCR-grade water (Solis BioDyne, Tartu, Estonia). Thermal cycling conditions consisted of polymerase activation at $95{ }^{\circ} \mathrm{C}$ for $30 \mathrm{~s}$, followed by 40 cycles of $95{ }^{\circ} \mathrm{C}$ for $5 \mathrm{~s}, 63^{\circ} \mathrm{C}$ for $15 \mathrm{~s}$, and $72{ }^{\circ} \mathrm{C}$ for $10 \mathrm{~s}$ and then a melt programme of $95{ }^{\circ} \mathrm{C}$ for $15 \mathrm{~s}, 55^{\circ} \mathrm{C}$ for $15 \mathrm{~s}$, and $95{ }^{\circ} \mathrm{C}$ for $15 \mathrm{~s}$. Reactions were carried out using the $\mathrm{Eco}^{\mathrm{Tm}}$ Real-Time PCR System (Illumina Inc., CA, USA). A negative control (no DNA template) was included in all series of reactions, and each experiment was performed twice. Cycle threshold values $(\mathrm{Cq})$ values were compared and a cycle threshold of 35 cycles was set as the amplification cutoff to eliminate the potential false-positive amplification. Selected real-time PCR products were electrophoresed to confirm that the amplicons were the expected size.

Prior to DNA sequencing, PCR products were treated with Exonuclease I (Exo) and Shrimp Alkaline Phosphatase (SAP) (Fermentas, Thermo Fischer Scientific, Waltham, MA, USA). DNA sequencing was performed on a 3500 Genetic Analyzer machine (Applied Biosystems), using BigDye ${ }^{\circledast}$ Terminator v3.1 Cycle Sequencing Kit (Applied Biosystems), according to the manufacturer's instructions. DNA sequencing was performed in both directions with ITS1-F and ITS4 primers for both $C$. minus-type strains used in this study (Additional file 1: Table S1). The DNA sequences were analysed using the Geneious software (version 7.1.3) described above.

\section{Specificity and sensitivity testing of Cyclaneusma morphotype-specific PCR primers}

The primers designed in this study ( $\mathrm{Cm}$ simile- and $\mathrm{Cm}$ verum-specific ITS primers, Table 1) were tested using DNA from fungal and oomycete species (Additional file 1: Table S1) that are associated with $P$. radiata, as well as $P$. radiata DNA. Conventional PCRs were performed at annealing temperatures of 60 and $63{ }^{\circ} \mathrm{C}$ to determine the annealing temperature that would yield an amplicon with the $\mathrm{Cm}$ simile- and $\mathrm{Cm}$ verum-specific ITS primers using the $\mathrm{Cm}$ simile and $\mathrm{Cm}$ verum DNA, respectively, indicating PCR specificity. The specificity of these primers was also tested at $63{ }^{\circ} \mathrm{C}$ using realtime PCR with SYBR-green.

To assess the sensitivity of the PCR reactions to detect the different morphotypes, both conventional and realtime PCR were used with serially diluted genomic DNA from simile and verum cultures. DNA was diluted tenfold with sterile PCR-grade water to concentrations ranging from $100 \mathrm{ng} . \mu \mathrm{L}^{-1}$ to $10 \mathrm{fg} . \mu \mathrm{L}^{-1}$ and amplified with both sets of MOTU-specific primers (Table 1). A negative control (water only) was included for each series of reactions and PCR products were visualised by agarose gel electrophoresis for the conventional PCRs or using a Cq cutoff of 35 cycles for real-time PCR, as described above.

\section{Detection of Cyclaneusma spp. in symptomatic $P$. radiata needles}

Needles were collected from two sites in January 2014 (both on Long Mile Road, Rotorua, New Zealand) for direct testing for the presence of $C$. minus using the MOTU-specific primers. Each sample contained two fascicles from a tree that was chosen based on the existence of characteristic symptoms of CNC (yellow mottling and easily detached needles). From the first sample site, 7 samples were collected from individual trees and from the second site, a further 11 samples were collected from individual trees. The needles were frozen overnight at $-20{ }^{\circ} \mathrm{C}$ then freeze-dried for 24-48 h. Whole needles were ground to a fine powder using liquid nitrogen and a mortar and pestle. The DNA was extracted using a modified method (Stöger and Ruppitsch 2004) with the Extract-N-Amp PCR ReadyMix kit (Sigma-Aldrich, MO, USA). RedExtract-N-Amp ${ }^{\text {TM }}$ extraction buffer $(400 \mu \mathrm{L})$ was added to the powdered needles, and the tubes were vortexed for $20 \mathrm{~s}$ and then incubated at $90{ }^{\circ} \mathrm{C}$ for $30 \mathrm{~min}$. The RedExtract-N-Amp ${ }^{\mathrm{Tm}}$ dilution 
buffer was added $(400 \mu \mathrm{L})$, and the tube was vortexed again for $20 \mathrm{~s}$. The extracts were then diluted 1:10 (in a 1:1 ratio of extraction:dilution buffers as the diluent), and $5 \mu \mathrm{L}$ of the diluted extracts were used per PCR reaction (Stöger and Ruppitsch 2004). PCR was performed using the RedExtract-N-Amp ${ }^{\text {Tw }}$ PCR ReadyMix, according to the manufacturer's instructions. A second round of PCR using the KAPA2G Robust HotStart Readymix $(2 \times)$ was performed using the first round as template due to the possibility of low fungal DNA titre.

\section{Results}

\section{Morphological analysis of Cyclaneusma minus cultures}

The morphology of $C$. minus in culture is known to be influenced by many factors including culture-type, the type of media, and the length of time they are grown (Dick et al. 2001). The appearance of C. minus cultures was highly variable on $2 \%$ malt agar medium in the current study. Isolates were assigned a morphotype using colony descriptions from Dick et al. (2001) prior to PCR. Of the 88 cultures analysed by morphology in this study, 44 were assigned to the simile morphotype and 39 were assigned to the verum morphotype (Additional file 1: Table S1) based on culture morphology alone. For five isolates, the assignment of morphotype based on colony morphology was obtained from N. Turner and M. Dick (unpublished data).

\section{Specificity and sensitivity of Cyclaneusma minus specific primers}

The C. minus MOTU-specific primers were tested against a range of fungal and oomycete DNA of species that are associated with $P$. radiata, as well as $P$. radiata DNA, to check the PCR specificity. The assignment of the DNA to either the simile morphotype or the verum morphotype are shown in Additional file 1: Table S1. PCR was most specific at an annealing temperature of $63{ }^{\circ} \mathrm{C}$, when tested using conventional PCR, as only the C. minus simile and verum positive controls amplified at this temperature. SYBR-green real-time PCR was also used to trial the PCR specificity at $63{ }^{\circ} \mathrm{C}$ with the MOTU-specific primers. Using the $\mathrm{Cm}$ simile primers, DNA from Diplodia sapinea strain 15B amplified at an average of 33 cycles, but all other fungal and oomycete DNA preparations tested only showed late (36-39 cycles) or inconsistent amplification (data not shown). Specificity testing with the $\mathrm{Cm}$ verum primers and SYBR-green real-time PCR showed late ( $\geq 39$ cycles) and inconsistent amplification of DNA from Phytophthora kernoviae and Diplodia pinea, but not from any other fungal or oomycete DNA preparations tested. Melting curve analysis of the fungal or oomycete reactions revealed $\mathrm{Tm}$ values that differed from the Cyclaneusma reactions, confirming that it was cross-amplification occurring late in the PCR cycling (data not shown). In addition, sequencing of the D. sapina amplicon yielded a DNA sequence with low sequence identity to sequences that were not ITS genes or from $D$. sapinea (data not shown).

The sensitivity of the PCR primers was assessed with conventional and real-time PCR and serially diluted genomic DNA. The $\mathrm{Cm}$ simile and $\mathrm{Cm}$ verum MOTU-specific primers could detect 0.1 and $1 \mathrm{pg}$ of DNA, respectively (at 35 cycles or less), using realtime PCR. The limit of detection using conventional PCR with the $\mathrm{Cm}$ simile and $\mathrm{Cm}$ verum MOTUspecific primers was 1 and $10 \mathrm{pg}$, respectively (data not shown). Real-time PCR analysis also showed that the simile primers did amplify some verum isolates DNA at $\mathrm{Cq}$ values of $\geq 35$ cycles and the verum primers did amplify some simile isolates DNA at $\mathrm{Cq}$ values of $\geq 37$ cycles.

The results of both the specificity and sensitivity testing suggests that 35 cycles is an essential cutoff value for positive amplification with these assays to prevent assigning false-positive results from non-specific amplification late in PCR cycling.

\section{PCR and DNA sequence analysis of Cyclaneusma minus and $C$. niveum type strains}

DNA from type strains of $C$. minus and $C$. niveum was analysed with both the ITS1-F and ITS4 primers and the $\mathrm{Cm}$ simile and $\mathrm{Cm}$ verum MOTU-specific primers (Table 1). PCR amplification using the ITS1-F and ITS4 primers yielded a PCR amplicon from each species that differed in size by approximately $200 \mathrm{bp}$ on an agarose gel. The C. minus CBS 496.73 isolate yielded an amplicon of approximately $600 \mathrm{bp}$, and the C. niveum CBS 495.73 isolate yielded an ITS amplicon of approximately 800 bp (Fig. 2). This result is in agreement with previously reported differences in ITS amplicon sizes for these species (Prihatini et al. 2014). These authors reported a 192bp indel in this gene region that related directly to the size difference of approximately $200 \mathrm{bp}$ observed on the gel. Cyclaneusma niveum and C. minus simile strains both produced an amplicon of approximately the same size (Fig. 2).

ITS DNA sequences obtained for the $C$. minus and $C$. niveum type-strains were submitted to the GenBank nucleotide sequence database (accession numbers KU170126 and KU170127). The Cm verum MOTUspecific primers successfully amplified DNA from $C$. minus type strain, but not from the $C$. niveum-type strain. The $\mathrm{Cm}$ simile MOTU-specific primers did not produce an amplicon with DNA from either of the type strains. 


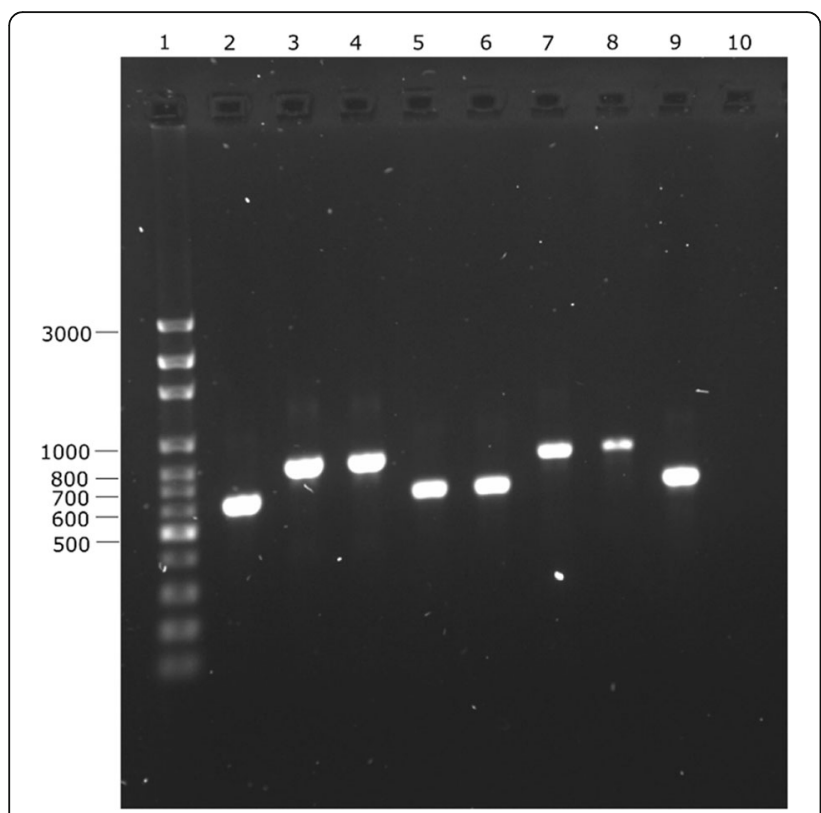

Fig. 2 DNA electrophoresis of ITS1-F and ITS4 PCR products from Cyclaneusma-type strains and isolates. Lanes: 1 100-bp ladder, 2 NZFS 4108, 3 NZFS 4177, 4 isolate 193/3, 5 NZFS 4086, 6 NZFS 4093, 7 NZFS 4111, 8 C. niveum-type strain CBS 495.73, 9 C. minus-type strain CBS 496.73, 10 no template PCR control

\section{Characterisation of Cyclaneusma minus isolates by PCR}

Characterisation of C. minus MOTUs was performed using two different PCR regions. Firstly, primers ITS1-F and ITS4 (Gardes and Bruns 1993; White et al. 1990) were used to differentiate the MOTUs based on the 192bp indel (Prihatini et al. 2014). C. minus verum produced a PCR amplicon of approximately $600 \mathrm{bp}$, and simile produced an amplicon of approximately $800 \mathrm{bp}$, clearly differentiated on an agarose gel (Fig. 2). Secondly, the MOTU-specific PCR primers $(\mathrm{Cm}$ simile-specific ITS and $\mathrm{Cm}$ verum-specific ITS, Table 1) were used to differentiate the simile and verum MOTUs based on nucleotide differences in the ITS gene region identified in DNA sequence alignments (Fig. 1, Additional file 1: Table S1). Both $C$. minus verum and simile produced the expected 390 bp amplicon on an agarose gel (data not shown). Real-time PCR analysis of these DNA preparations, with the same MOTU-specific primers, produced results similar to those observed with conventional PCR.

PCR was performed on DNA from 120 C. minus strains, isolated from 1969 to 2008 using both conventional PCR and real-time PCR. From these isolates, 25 were assigned to the verum MOTU and 95 were assigned to the simile MOTU (Additional file 1: Table S1). When compared to the morphological analysis, the PCR results were consistent with morphotypes for $56 \%$ of the isolates.
Discrepancies in the PCR-based characterisation were observed for several isolates: NZFS 752, 753, 759, and 3325 (Additional file 1: Table S1), despite several attempts. DNA from isolates NZFS 752, 753, and 759 all yielded a PCR amplicon using both sets of MOTU-specific primers primers with both conventional and SYBR-green PCR. PCR with the ITS primers indicated that 752 and 753 were verum, and 759 was simile and DNA sequencing confirmed these results by identification of the 192-bp indel. DNA from isolate NZFS 3325 amplified with the ITS primers to yield a PCR product of approximately $600 \mathrm{bp}$, indicating that this belongs to the verum MOTU. However, using the Cm-specific verum or simile MOTU-specific primers in SYBR-green PCR, late amplification was observed (>35 cycles), and no amplification was observed with conventional PCR. DNA sequencing of the ITS PCR product for NZFS 3325 revealed that this isolate had a DNA sequence variable to both the simile and verum MOTUs and with only $85 \%$ sequence identity to the $C$. minus- and C. niveum-type strains. The closest hit when analysed by BLASTn was Naemacyclus minor (90\% sequence identity, accession number KJ606680).

\section{Detection of Cyclaneusma spp. from symptomatic $P$. radiata needles}

Conventional PCR was used to detect $C$. minus from fresh, symptomatic pine needle tissue but low rates of DNA detection were observed. For this reason, two rounds of PCR were performed to increase the possibility of detection from potentially low fungal DNA titres. In the first round of PCR, testing for the presence of $C$. minus directly with the MOTU-specific primers, simile was detected from the needles of two samples and verum was not detected in any. This was most likely due to low pathogen DNA titre in the pine extract. Therefore, the PCR was repeated using the first round PCR product as the template, where 9 out of the 18 samples amplified in the second round of PCR. Overall, C. minus simile was detected in seven samples and $C$. minus verum was detected in two. No samples showed the presence of both MOTUs.

\section{Distribution of Cyclaneusma minus simile and verum}

From the 120 cultures analysed in this study, the simile MOTU was the most frequently detected at $79 \%$. The simile MOTU comprised $89 \%$ of all North Island isolates and 59\% of South Island isolates (Table 2). CNC is most prevalent in the North Island, particularly in Northland, Auckland, and the central North Island (Bulman 1988). Isolates from these regions also comprised a large number of simile MOTUs when tested with the MOTUspecific primers (Table 3 ). 
Table 2 Distribution of Cyclaneusma minus MOTUs in New Zealand based on molecular analyses of samples in this study

\begin{tabular}{lll}
\hline $\begin{array}{l}\text { Distribution within } \\
\text { New Zealand }\end{array}$ & $\begin{array}{l}\text { Cyclaneusma minus } \\
\text { 'simile' (\%) }\end{array}$ & $\begin{array}{l}\text { Cyclaneusma minus } \\
\text { 'verum' (\%) }\end{array}$ \\
\hline North Island & 89 & 11 \\
South Island & 59 & 41 \\
Overall & 79 & 21 \\
\hline
\end{tabular}

\section{Discussion}

This work describes new molecular tools for the detection of Cyclaneusma species, using both conventional and real-time PCR and represents the first molecular study of the prevalence of the known $C$. minus morphological types, with reference to geographical distribution in New Zealand.

Characterisation of the two morphological types, $C$. minus verum and $C$. minus simile, has been previously described, where only the $C$. minus verum morphotype is considered to share characters with the $C$. minus type-

Table 3 Distribution of Cyclaneusma minus MOTUs in New Zealand Regions Crosby et al. (1998)

\begin{tabular}{|c|c|c|c|}
\hline Region & Total (n) & $\begin{array}{l}\text { Cyclaneusma } \\
\text { minus 'simile' }\end{array}$ & $\begin{array}{l}\text { Cyclaneusma } \\
\text { minus 'verum' }\end{array}$ \\
\hline Auckland, NI & 9 & 9 & 0 \\
\hline Bay of Plenty, NI & 12 & 7 & 5 \\
\hline Coromandel, NI & 2 & 1 & 1 \\
\hline Central Otago, SI & 2 & 0 & 2 \\
\hline Dunedin, SI & 4 & 1 & 3 \\
\hline Fiordland, SI & 4 & 0 & 4 \\
\hline Gisborne, NI & 7 & 7 & 0 \\
\hline Hawke's Bay, NI & 4 & 2 & 2 \\
\hline Marlborough, SI & 2 & 2 & 0 \\
\hline North Canterbury, SI & 2 & 0 & 2 \\
\hline Northland, NI & 9 & 9 & 0 \\
\hline Nelson, SI & 6 & 6 & 0 \\
\hline Otago Lakes, SI & 1 & 0 & 1 \\
\hline Rangitikei, NI & 3 & 3 & 0 \\
\hline South Canterbury, SI & 1 & 0 & 1 \\
\hline Marlborough Sounds, SI & 3 & 2 & 1 \\
\hline Southland, SI & 9 & 7 & 2 \\
\hline Taranaki, NI & 3 & 3 & 0 \\
\hline Taupo, NI & 13 & 12 & 1 \\
\hline Wairarapa, NI & 3 & 3 & 0 \\
\hline Westland, SI & 5 & 5 & 0 \\
\hline Wanganui, NI & 2 & 2 & 0 \\
\hline Wellington, $\mathrm{NI}$ & 10 & 10 & 0 \\
\hline Waikato, NI & 4 & 4 & 0 \\
\hline
\end{tabular}

NI North Island, SI South Island strain (Dick et al. 2001). Using the molecular method designed in this study, and based on the 192bp indel identified by Prihatini et al. (2014), we have confirmed that the verum MOTU from New Zealand is consistent with the C. minus-type strain (CBS 496.73). Molecular analysis with DNA from the C. niveum type strain (CBS 495.73) indicated that this species has the 192bp region absent in verum and the $C$. minus-type strain. The ITS1F and ITS4 amplicon from C. niveum was the same size as that observed for $C$. minus simile, confirming the results observed by Prihatini et al. (2014). This also indicates that the ITS1-F and ITS4 PCR is not sufficient alone to differentiate the two $C$. minus morphotypes.

The molecular assays designed in this study could differentiate morphotypes when used in either conventional or real-time PCR. However, some cross-amplification did occur at an annealing temperature of $60{ }^{\circ} \mathrm{C}$ (lower than the optimal $63{ }^{\circ} \mathrm{C}$ ) or late in PCR cycling (i.e., Cq values greater than 35 ) indicating the need to adhere to stringent cycling conditions to maintain specificity. The incorporation of both verum and simile DNA as positive and negative controls for each assay is also useful. The limits of detection for these assays were within the range of other species-specific PCR assays for pine pathogens, in the picogram range of DNA detection (Duran et al. 2009; Ioos et al. 2010) and indicating a good level of PCR sensitivity. The Cm simile specific PCR assay was ten-fold more sensitive than the $\mathrm{Cm}$ verum assay, and real-time PCR was ten-fold more sensitive than the conventional PCR in these assays.

When compared to the morphological analysis (using gross colony morphology alone), the PCR results were consistent with morphotype $56 \%$ of the time. This level of consistency is lower than previously reported in Prihatini et al. (2014), although their study used isolates selected for clear morphological differences and did not include isolates whose morphology was equivocal. Similar to the results observed in this study, Prihatini et al. (2015) also detected the simile MOTU more commonly than the verum one in a $P$. radiata trial site in Tasmania, Australia. This result contrasts with a recent study in Europe using these primers, where the verum MOTU was identified from several pine samples but simile was not (D. Nguyen, personal comm.). It has been previously suspected that there may be more than two morphotypes of C. minus (M. Dick, R. Ganley, pers. comm) based on observations from previous studies investigating endophytic species associated with $P$. radiata. In this study, we identified an isolate, NZFS 3325, with DNA sequence variation in the ITS region to both the simile and verum MOTUs. The $\mathrm{Cm}$ simile and $\mathrm{Cm}$ verum MOTU-specific primers were not effective with this isolate. Further sequencing of DNA regions from existing and new isolates might elucidate the population 
structure of $C$. minus sensu lato on $P$. radiata. The use of morphological methods alone requires a high level of expertise and a considerable amount of time to grow the cultures, especially if using morphological characters such as apothecium and ascospore size for differentiation (Dick et al. 2001). Therefore, the molecular tools described here can be used to increase the accuracy and decrease the time required to differentiate these morphotypes.

Two rounds of PCR were typically required to detect C. minus in infected needles when using the methods described in this study. This additional step increases the time and resources required for detection but is still faster than using culture-based methods alone with this particular pathogen (Dick et al. 2001). Considering the high level of PCR sensitivity obtained with genomic DNA in these assays, the low detection rates observed for $C$. minus from pine needles may indicate that the DNA extraction method used may not be efficient enough for pathogen detection from $P$. radiata. Obtaining high-quality DNA from pine needle samples can be difficult due to high amounts of co-contaminants (Telfer et al. 2013). Comparisons of DNA extraction methods have been performed to identify the best method for obtaining high-quality DNA for PCR from $P$. radiata (Ioos et al. 2010; Telfer et al. 2013), and these methods should be tested for improved detection of $C$. minus from infected pine needles.

Samples were collected mid-summer when $\mathrm{CNC}$ disease expression is not typically high, so there may have been a low titre of pathogen DNA, even though Cyclaneusma spp. are known to be present as endophytes (Helander et al. 1994; Kowalski 1993; Sieber et al. 1999). It is not usually possible to identify specific points of $C$. minus infection as it is endophytic and will cause visible infection only under certain conditions. Infection is indicated by yellow-green mottling and usually occurs along the entire length of the needle, hence the reason whole needles were analysed. C. minus can be detected from pine needles by growing out the fungus, and this approach has been used successfully in both symptomatic and asymptomatic needles (R.J. Ganley, pers. comm.). However, the growth of this fungus is very slow (Dick et al. 2001; Ganley et al. 2015).

Utilising recommended methods for DNA extractions from pine needles (Ioos et al. 2010; Telfer et al. 2013), together with sampling during periods of high disease expression, should overcome the detection issues encountered with pine needle samples during this study. Probe-based diagnostic assays using realtime PCR assays as well as nested PCR primers for differentiating the morphotypes are currently being developed, which will also improve detection from infected material.
The results obtained in this study showed that the simile MOTU was most common in areas in New Zealand where the disease was most prevalent. This observation does not necessarily indicate that the simile MOTU is the causative agent of CNC as other factors, including the environment and climate, could also play important roles. It is also possible that a level of bias exists in the sampling by using isolates obtained from pine needles, as opposed to detecting the DNA directly from the needles themselves, due to potential differences in growth rates and isolation frequencies of the different morphotypes. Further work involving detection of MOTUs directly from pine needles using the quantitative real-time PCR assays developed in this study will hopefully address these issues.

Knowledge of the diversity and distribution of C. minus MOTUs will contribute to enhanced understanding of the potential roles of the different $C$. minus MOTUs in CNC. The most promising method for control currently appears to be cultivation of tolerant or resistant $P$. radiata genotypes so it is necessary to understand the genetic diversity within the genus Cyclaneusma in order to successfully identify the best genotypes for cultivation on diseaseprone sites. As suggested by Prihatini et al. (2014), a new species description for the C. minus simile morphotype would also be helpful for delineating the causative agents involved in $\mathrm{CNC}$ disease.

\section{Conclusions}

Molecular assays have been developed that are able to identify the $C$. minus morphotypes simile and verum and are able to rapidly and accurately designate $C$. minus isolates to the different MOTUs. The described molecular method can be used with infected pine needles; however, further work is required to improve detection from infected plant material. Nonetheless, the described molecular tools can considerably reduce the time taken to differentiate the morphotypes of this slow-growing pine pathogen.

Cyclaneusma minus simile was the most prevalent morphotype found in association with $P$. radiata, in both the North and South Islands of New Zealand. The molecular identification of $C$. minus simile and verum from cultured isolates was only consistent with morphological identifications $56 \%$ of the time. This shows the molecular assay developed in this study is considerably more accurate than morphological assessments, likely due to morphological variations that are observed in culture.

Knowledge of the diversity and distribution of $C$. minus MOTUs will contribute to enhanced understanding of the role these morphotypes play in disease expression of $\mathrm{CNC}$ in the field. In the long term, however, this new knowledge is expected to improve identification of 
$P$. radiata material that is more resistance to this disease, thus allowing propagation for deployment to high disease-prone sites.

\section{Additional file}

Additional file 1: Table S1. Strains used in this study and MOTUspecific PCR results $(n=120)$. Description: this data is a table of all isolates tested, including the two Cyclaneusma type strains ( $n=122)$, collection dates and locations and all PCR results. It also lists a small collection of additional fungi and oomycetes used to test specificity of the described PCR primers. (PDF $430 \mathrm{~kb}$ )

\section{Abbreviations}

CNC: Cyclaneusma needle cast; ITS: Internal transcribed spacer; MOTU: Molecular operational taxonomic unit; PCR: Polymerase chain reaction

\section{Acknowledgements}

Core-funding from the New Zealand Ministry of Business Innovation and Employment (MBIE) and the New Zealand Forest Growers Levy Trust (FGLT) are acknowledged for financial support. The authors would also like to acknowledge Scion's Forest Genetics team for access to infected plant material. Scion's Forest Research Culture Collection supplied all the New Zealand isolates used in this study. L. Cunningham, R. Tetenburg and P. Taylor are thanked for technical assistance. B. Weir, M. Petterson and D. Park (Landcare Research) and the ICMP collection are acknowledged for assistance with importation of Cyclaneusma spp.-type strains and providing DNA extracts. L. Bulman and R. Ganley are thanked for helpful suggestions on the first version of the manuscript.

\section{Authors' contributions}

$\mathrm{SH}$ performed the morphological and molecular analyses and assisted with the sample collection and writing of the manuscript. MG designed the MOTU-specific PCR primers, contributed to the DNA sequence alignments, and reviewed the manuscript drafts. RM designed and coordinated the project and assisted with the sample collection, DNA sequence analysis, and manuscript preparation. All authors have read and approved the final manuscript.

\section{Competing interests}

The authors declare that they have no competing interests.

\section{Author details}

${ }^{1}$ Scion, New Zealand Forest Research Institute Ltd., Private Bag 3020, Rotorua 3046, New Zealand. ${ }^{2}$ Tasmanian Institute of Agriculture, University of Tasmania, Private Bag 54, Hobart, TAS 7001, Australia.

\section{Received: 13 January 2016 Accepted: 18 November 2016}

Published online: 13 December 2016

\section{References}

Altschul, S. F., Gish, W., Miller, W., Myers, E. W., \& Lipman, D. J. (1990). Basic local alignment search tool. Journal of Molecular Biology, 215(3), 403-410. doi: 10. 1016/S0022-2836(05)80360-2.

Bednářová, M., Dvořák, M., Janoušek, J., \& Jankovský, L. (2013). Other foliar diseases of coniferous trees. In P Gonthier, \& G Nicolotti (Eds.), Infectious Forest Diseases (pp. 458-487). Oxfordshire: CABI.

Bulman, L. (2009). Quantifying pest impact and spread: Cyclaneusma needle-cast (Forest Biosecurity and Protection Annual Science Report 2009). Rotorua: Scion.

Bulman, L. S. (1988). Incidence and severity of cyclaneusma needle-cast in fifteen Pinus radiata plantations in New Zealand. New Zealand Journal of Forestry Science, 18(1), 92-100.

Bulman, L. S., \& Gadgil, P. D. (Eds.). (2001). Cyclaneusma needle-cast in New Zealand, Forest Research Bulletin No. 222. Rotorua: Forest Research.

Choi, D., \& Simpson, J. A. (1991). Needlecast of Pinus radiata in New South Wales. Australian Journal of Botany, 39, 137-152.
Crosby, T. K., Dugdale, J. S., \& Watt, J. C. (1998). Area codes for recording specimen localities in the New Zealand subregion. New Zealand Journal of Zoology, 25(2), 175-183. doi: 10.1080/03014223.1998.9518148.

Crous, P. W., Wingfield, M. J., \& Swart, W. J. (1990). Shoot and needle diseases of Pinus spp. in South Africa. Southern African Forestry Journal, 154, 60-66.

Dick, M. A., Somerville, J. G., \& Gadgil, P. D. (2001). Variability in the fungal population. In L. S. Bulman \& P. D. Gadgil (Eds.), Cyclaneusma needle-cast in New Zealand, Forest Research Bulletin No. 222 (pp. 12-19). Rotorua: Forest Research Institute Ltd

DiCosmo, F., Peredo, H., \& Minter, D. W. (1983). Cyclaneusma gen. nov., Naemacyclus and Lasiostictis, a nomenclatural problem resolved. European Journal of Forest Pathology, 13, 206-212.

Dungey, H. S., Low, C. B., \& Bulman, L. S. (2006). Needle cast in New Zealand-are there opportunities for improvement in plantation growth? Paper presented at the Breeding for Success: Diversity in Action. Christchurch: Proceedings of the 13th Australasian Plant Breeding Conference. 18-21 April, 2006. 497-504.

Duran, A., Slippers, B., Gryzenhout, M., Ahumada, R., Drenth, A., Wingfield, B. D., \& Wingfield, M. J. (2009). DNA-based method for rapid identification of the pine pathogen, Phytophthora pinifolia. FEMS Microbiology Letters, 298(1), 99-104. doi: 10.1111/j.1574-6968.2009.01700.x.

Gadgil, P. D. (1984). Cyclaneusma (Naemacyclus) needle-cast of Pinus radiata in New Zealand. 1. Biology of Cyclaneusma minus. New Zealand Journal of Forestry Science, 14(2), 179-196.

Ganley, R. J., Hargreaves, C. L., \& Donaldson, L. A. (2015). Detection of asymptomatic fungal microorganisms in Pinus radiata tissue culture material. New Zealand Journal of Forestry Science, 45(1), 11. doi: 10.1186/s40490-0150042-y.

Gardes, M., \& Bruns, T. D. (1993). ITS primers with enhanced specificity for basidiomycetes - application to the identification of mycorrhizae and rusts. Molecular Ecology, 2, 113-118.

Giordano, L., \& Gonthier, P. (2011). An outbreak of Cyclaneusma minus needle cast on Swiss mountain pine (Pinus uncinata) in Italy. Journal of Plant Pathology, 93(SUPPL 4), S4.74.

Helander, M. L., Sieber, T. N., Petrini, O., \& Neuvonen, S. (1994). Endophytic fung in Scots Pine needles - spatial variation and consequences of simulated acid-rain. Canadian Journal of Botany, 72(8), 1108-1113.

Hood, I. A., \& Vanner, A. L. (1984). Cyclaneusma (Naemacyclus) needle-cast of Pinus radiata in New Zealand. 4. Chemical control research. New Zealand Journal of Forestry Science, 14, 215-222.

loos, R., Fabre, B., Saurat, C., Fourrier, C., Frey, P., \& Marçais, B. (2010). Development, comparison, and validation of real-time and conventional PCR tools for the detection of the fungal pathogens causing brown spot and red band needle blights of pine. Phytopathology, 100(1), 105-114.

Katoh, K., Misawa, K., Kuma, K., \& Miyata, T. (2002). MAFFT: a novel method for rapid multiple sequence alignment based on fast Fourier transform. Nucleic Acids Research, 30(14), 3059-3066.

Kearse, M., Moir, R., Wilson, A., Stones-Havas, S., Cheung, M., Sturrock, S., Buxton, S., Cooper, A., Markowitz, S., Duran, C., Thierer, T., Ashton, B., Meintjes, P., \& Drummond, A. (2012). Geneious Basic: an integrated and extendable desktop software platform for the organization and analysis of sequence data. Bioinformatics, 28(12), 1647-1649. doi: 10.1093/bioinformatics/bts199.

Kistler, B. R., \& Merrill, W. (1977). Etiology, symptomology, epidemiology and control of Naemacyclus needle-cast of Scots pine. Phytopathology, 68, 267-271.

Kowalski, T. (1993). Fungi in living symptomless needles of Pinus sylvestris with respect to some observed disease processes. Journal of Phytopathology, 139, 129-145.

New Zealand Forest Owners Association, I. (2012). New Zealand plantation forest industry facts \& figures. 2011/2012 ed.

Podger, F. D., \& Wardlaw, T. J. (1990). Spring needle-cast of Pinus radiata in Tasmania: I. Symptoms, distribution, and association with Cyclaneusma minus. New Zealand Journal of Forestry Science, 20(2), 184-205.

Prihatini, I., Glen, M., Wardlaw, T. J., \& Mohammed, C. L. (2014). Multigene phylogenetic study of Cyclaneusma species. Forest Pathology, 44(4), 299-309. doi: 10.1111/efp.12101.

Prihatini, I., Glen, M., Wardlaw, T. J., \& Mohammed, C. L. (2015). Lophodermium pinastri and an unknown species of Teratosphaeriaceae are associated with needle cast in a Pinus radiata selection trial. Forest Pathology. doi: 10.1111/ efp.12169.

Sieber, T. N., Rys, J., \& Holdenrieder, O. (1999). Mycobiota in symptomless needles of Pinus mugo ssp. uncinata. Mycological Research, 103, 306-310. doi: 10. 1017/S0953756298007229. 
Stöger, A., \& Ruppitsch, W. (2004). A rapid and sensitive method for the detection of Xanthomonas fragariae, causal agent of angular leafspot disease in strawberry plants. Journal of Microbiological Methods, 58(2), 281-284. doi: 10 1016/j.mimet.2004.04.002.

Telfer, E., Graham, N., Stanbra, L., Manley, T., \& Wilcox, P. (2013). Extraction of high purity genomic DNA from pine for use in a high-throughput Genotyping Platform. New Zealand Journal of Forestry Science, 43(1), 1-8. doi: 10.1186/ 1179-5395-43-3.

van der Pas, J. B., Slater-Hayes, J. D., Gadgil, P. D., \& Bulman, L. S. (1984). Cyclaneusma (Naemacyclus) needle-cast of Pinus radiata in New Zealand 2: reduction in growth of the host, and its economic implication. New Zealand Journal of Forestry Science, 14(2), 197-209.

White, T. J., Bruns, T., \& Taylor, J. (1990). Amplification and direct sequencing of fungal ribosomal RNA genes for phylogenetics. In PCR Protocols: A Guide to Methods and Applications (pp. 315-322): Academic Press, Inc.

\section{Submit your manuscript to a SpringerOpen ${ }^{\circ}$ journal and benefit from:}

- Convenient online submission

- Rigorous peer review

- Immediate publication on acceptance

- Open access: articles freely available online

- High visibility within the field

- Retaining the copyright to your article

Submit your next manuscript at $\boldsymbol{s p r i n g e r o p e n . c o m ~}$ 